\title{
THE LAW AS A SPECIFIC SOCIAL TECHNIQUE*
}

\author{
HaNS KELSEN† \\ THE ESSENCE OF LEGAL TECHNIQUE
}

I. SOCLAL TECHNIQUE OF DIRECT AND INDIRECT MOTIVATION

HE living together of human beings is characterized by the setting up of institutions that regulate this living together. Such an institution is called an "order." The living together of individuals, in itself a biological phenomenon, becomes a social phenomenon by the very fact of being regulated. Society is ordered living together, or, more accurately put, society is the ordering of the living together of individuals.

The function of every social order is to bring about certain mutual behavior of individuals; to induce them to certain positive or negative behavior, to certain action or abstention from action. To the individual the order appears as a complex of rules that determine how the individual should conduct himself. These rules are called norms.

According to the manner in which the socially desired behavior is brought about, various types of social orders can be distinguished. These types-it is ideal types that are to be presented here-are characterized by the specific motivation resorted to by the order to induce individuals to behave as desired. The motivation may be indirect or direct. The order may attach certain advantages to its observance and certain disadvantages to its non-observance, and hence make desire for the promised advantage or fear of the threatened disadvantage a motive for behavior. Behavior conforming to the order is achieved by a sanction provided by the order itself. The principle of reward and punishment-the principle of retribution-fundamental for social living, consists in associating conduct in accordance with the order and conduct contrary to the order with a promised advantage or a threatened disadvantage respectively, as sanctions.

The order can, however, even without promise of a reward in case of

*A portion of this paper was presented at a Fiftieth Anniversary symposium of the University of Chicago, September 25, 194r.

$\uparrow$ Research Associate in Comparative Law, Harvard University; formerly Professor at the University of Vienna, the University of Cologne, the Graduate Institute of International Studies at Geneva, the German University of Prague, and Holmes Lecturer at Harvard University. 
obedience and without threat of a disadvantage in case of disobedience, i.e., without decreeing sanctions, require conduct that appeals directly to the individuals as advantageous, so that the mere idea of a norm decreeing this behavior suffices as a motive for conduct conforming to the norm. This type of direct motivation is seldom to be met with in social reality in its full purity.

In the first place, there are hardly any norms the purport of which appeals directly to the individuals whose conduct they regulate so that the mere idea of them suffices for motivation. Moreover, the social behavior of individuals is always accompanied by a judgment of value, namely, the idea that conduct in accordance with the order is "good" whereas that contrary to the order is "bad." Hence obedience to the order is usually connected with the approval of one's fellow men; disobedience, with their disapproval. The effect of this reaction of the group to conduct of the individuals in accordance with or at variance to the order, is that of a sanction of the order. From a realistic point of view the decisive difference is not between social orders whose efficacy rests on sanctions and those whose efficacy is not based on sanctions. Every social order is somehow "sanctioned" by the specific reaction of the community to conduct of its members corresponding to or at variance with the order. This is also true of highly developed moral systems, which most closely approach the type of direct motivation by sanctionless norms. The only difference is that certain social orders themselves provide definite sanctions, whereas in others, the sanctions consist in the automatic reaction of the community not expressly provided by the order.

The sanctions provided by the social order itself may have a transcendental, that is a religious, or a social-immanent character.

In the first case, the sanctions provided by the order consist in advantages or disadvantages that are to be applied to the individuals by a superhuman authority, a being characterized more or less as God-like. According to the idea that individuals have of superhuman beings, in the beginnings of religious development, they exist not in a Hereafter different from the Here, but closely connected with men in the nature surrounding them. The dualism of the Here and the Hereafter is still unknown to primitive man. His first gods are the souls of the dead, especially dead ancestors, that live in trees, rivers, rocks, and especially in certain animals. It is they that guarantee the maintenance of the primitive social order by punishing its violation with death, sickness, unluckiness in the chase, and in similar ways and by rewarding its observance with long life, health, and luck in hunting. Retribution does indeed emanate from di- 
vinity, but it is realized Here. For nature is explained by primitive man according to the principle of retribution. The earliest social order has a completely religious character. Originally it knows no sanctions other than religious ones, that is, those emanating from a superhuman authority. Only later, at least within the narrower group itself, do there appear, side by side with the transcendental sanctions, sanctions that are socially immanent, that is to say, socially organized, to be fulfilled by the individuals according to the provisions of the social order. In relations among the groups, blood revenge appears very early as a reaction against an injury considered unjustified and due to a member of a foreign group.

The group from which this reaction issues is a community based on blood relationship. The reaction is induced by fear of the soul of the murdered person. The latter cannot revenge himself upon his murderer if he belongs to a foreign group. Hence he compels his relatives to carry out the revenge. The sanction so socially organized is itself guaranteed by a transcendental sanction. Those who fail to revenge the death of their relative upon the foreign murderer and his group are threatened with sickness and death by the murdered man. It seems that blood revenge is the earliest socially organized sanction. It is worthy of note that originally it had an inter-tribal character. Only when the social community comprises several groups based on blood relationship does blood revenge become an intra-tribal institution.

In the further course of religious development, the divinity is conceived of as pertaining to a realm very different from the Here, and far removed from it, and the realization of divine retribution is put off to the Hereafter. Very often this Hereafter is divided - corresponding to the two-fold character of retribution-into a heaven and a hell. In this stage, the social order has lost its purely religious character. The religious order functions only as a supplement and support to the social order. The sanctions of the latter are exclusively acts of human individuals regulated by the social order itself.

It is a fact well worth noting, that of the two sanctions here presented as typical-the disadvantage threatened in case of disobedience (punishment, in the broadest sense of the term), and the advantage promised in case of obedience (the reward)-in social reality, the first plays a far more important role than the second. That the technique of punishment is preferred to that of reward is especially clearly seen where the social order still has a distinctly religious character, i.e., is guaranteed by transcendental sanctions. In the case of primitive peoples, behavior conforming to the social order, especially the observance of the numerous prohibitions called 
"taboos," is determined principally by the fear that dominates the life of such peoples. It is fear of the grievous evil with which the superhuman authority reacts against every violation of traditional customs. If violations of the social norms are much less frequent in primitive societies than in civilized societies, as ethnologists report to be the case, it is principally this fear of the revenge of the spirits, fear of a punishment that is of divine origin but which takes place Here, which is responsible for this effect of preserving social order. The hope of reward has only a secondary significance. And even in more highly developed religions, where divine retribution is no longer or not only realized in this world, but in the Hereafter, the idea of a punishment to be expected after death holds first place. In the actual beliefs of mankind, fear of hell is much more lively and the picture of a place of punishment is much more concrete than the usually only very vague hope of reward in heaven and the utterly colorless idea of a future paradise. Even when the wish-fulfilling fantasy of individuals is not limited by any restrictions, it imagines a transcendental order the technique of which is not entirely different from the technique of empirical society.

This may be referrable to the fact that religious ideology always mirrors, more or less accurately, social reality. And in this, as far as the organization of the group is concerned, essentially only one method of bringing about socially desired behavior is taken into account: the threat and the application of an evil in case of contrary behavior-the technique of punishment. The technique of reward plays a significant role only in the private relations of individuals.

The evil applied to the violator of the order when the sanction is socially organized, consists in a deprivation of possessions - life, health, freedom, or property. As the possessions are taken from him against his will, this sanction has the character of a measure of coercion. This does not mean that in carrying out the sanction physical force must be applied. This is necessary only if resistance is encountered in applying the sanction. This is only exceptionally the case where the authority applying the sanction possesses adequate power. A social order that seeks to bring about the desired behavior of individuals by the enactment of such measures of coercion is called a coercive order. Such it is because it threatens socially harmful deeds with measures of coercion, and decrees such measures of coercion. As such it presents a contrast to all other possible social orders - those that provide reward rather than punishment as sanctions, and especially those that enact no sanctions at all, relying on the technique of direct motivation. In contrast to the orders that enact coercive 
measures as sanctions, the efficacy of the others rests not on coercion but on voluntary obedience.

Yet this contrast is not so distinct as it might at first sight appear. This is apparent from the fact that the reward, as a technique of indirect motivation, has its place between indirect motivation through punishment, as a technique of coercion, and direct motivation, the technique of voluntary obedience. Voluntary obedience is itself a form of motivation, that is of coercion, and hence is not freedom, but it is coercion in the psychological sense. The element of psychic coercion cannot serve as the criterion for distinguishing among different types of social orders. For the efficacy of every social order rests on psychic coercion, because it rests upon motivation. If coercive orders are contrasted with those that have no coercive character but rest on voluntary obedience, this is possible only in the sense that one enacts measures of coercion as sanctions whereas the other does not. And these sanctions are only coercive measures in the sense that certain possessions are taken from the individuals in question against their will.

In this sense the law is a coercive order.

II. IAW AS COERCIVE ORDER MONOPOIJZING THE USE OF FORCE

If the social orders, so extraordinarily different in their tenors, which have been in force at different times and among the most different peoples are all called legal orders, it might be supposed that one was using an expression almost devoid of meaning. What could the so-called law of ancient Babylonians have in common with the law-likewise so-calledthat prevails today in the United States? What could the social order of a Negro tribe under the leadership of a despotic chieftain have in common with the constitution of the Swiss Republic? Yet there is a common element which fully justifies this terminology, that enables the word "law" to appear as the expression of a concept with a socially highly significant meaning. For the word refers to that specific social technique of a coercive order, which, despite the vast differences between the law of ancient Babylon and that of the United States of today, between the law of the Ashantis in West Africa and that of the Swiss in Europe, is yet essentially the same for all these peoples differing so in time, in place, and in culture: the social technique which consists in bringing about the desired social conduct of men through threat of a measure of coercion which is to be applied in case of contrary conduct.

While recognizing law as the specific social technique of the coercive order, we can contrast it sharply with other social orders which pursue in 
part the same purposes as the law, but by quite different means. And law is a means, a specific social means, not an end. Law, morality, and religion-all three forbid murder. But the law does this by providing that if a man commits murder, then another man, designated by the legal order, shall apply against the murderer a certain measure of coercion, prescribed by the legal order. Morality limits itself to requiring: thou shalt not kill. And if a murderer is morally ostracized by his fellow-menand many an individual refrains from murder not so much because he wants to avoid the punishment of the law, as to avoid the moral disapprobation of his fellow-men - the great distinction still remains, that the reaction of the law consists in a measure of coercion enacted by the order, and socially organized, whereas the moral reaction against immoral conduct is neither provided by the moral order, nor, if provided, socially organized. In this respect religious norms are nearer to legal norms than moral norms are. For religious norms threaten the murderer with punishment by a superhuman authority. But the sanctions which the religious norms lay down have a transcendental character; they are not socially organized sanctions, even though provided by the religious order. They are probably more effective than the legal sanctions. Their efficacy, however, presupposes belief in the existence and power of a superhuman authority. It is not the effectiveness of the sanctions that is here in question, however, but only whether and how they are provided by the social order. The socially organized sanction is an act of coercion which a person determined by the order directs, in a manner determined by the order, against the person responsible for conduct contrary to the order. The sanction is the reaction of the order, or, what amounts to the same thing, the reaction of the community constituted by the order, to evildoers. The individual who carries out the sanction acts as an agent of the social community. The legal sanction is thus interpreted as an act of the legal community; the transcendental sanction-the sickness or death of the sinner-is an act of the superhuman authority of the deceased ancestors, of God.

Among the paradoxes of the social technique here characterized as a coercive order is the fact that its specific instrument, the coercive act, is of exactly the same sort as the act which it seeks to prevent in the relations of individuals; that the sanction against socially injurious behavior is itself such behavior. For that which is to be accomplished by the threat of forcible deprivation of life, health, freedom, or property is precisely that men in their mutual conduct shall refrain from forcibly depriving one another of life, health, freedom, or property. Force is employed to prevent the employment of force. 
This contradiction is only apparent, however. The law is, to be sure, an ordering for the promotion of peace, in that it forbids the use of force in relations among the members of the community. Yet it does not absolutely preclude the use of force. Law and force must not be understood as absolutely at variance with each other. Law is an organization of force. For the law attaches certain conditions to the use of force in relations among men, authorizing the employment of force only by certain individuals and only under certain circumstances. The law allows conduct which, under all other circumstances, is to be considered as "forbidden." To be forbidden means to be the very condition for such a coercive act as a sanction. The individual who, authorized by the legal order, applies the coercive measure (the sanction), acts as an organ of this order, or of the community constituted thereby. And hence one may say that law makes the use of force a monopoly of the community. And precisely by so doing, law pacifies the community.

Peace is a condition in which there is no use of force. In this sense of the word, law provides only relative, not absolute peace, in that it deprives the single individual of the right to employ force but reserves it for the community. The peace of the law is not a condition of absolute absence of force, a state of anarchy; it is a condition of monopoly of force, a force monopoly of the community.

A community, in the long run, is possible only if each individual respects certain interests-life, health, freedom, and property of everyone else-that is to say, if each refrains from forcibly interfering in these spheres of interest of the other. The social technique that we call "law" consists in inducing the individual, by a specific means, to refrain from forcible interference in the spheres of interests of others: in case of such interference, the legal community itself reacts with a like interference in the spheres of interests of the individual responsible for the previous interference. Forcible interference in the spheres of interests of another, the measure of coercion, functions as delict and also as sanction. Law is an order according to which the use of force is forbidden only as a delict, that is, as a condition, but is allowed as a sanction, that is, as a consequence.

Inasmuch as forcible interference in the spheres of interest of the individual is permitted only as a reaction of the community against prohibited conduct of that individual, inasmuch as forcible interference in the spheres of interest of the individual is made a monopoly of the community, definite spheres of interest of the individual are protected. As long as there exists no monopoly of the community in forcible interference in the spheres of interest of the individual, that is to say, as long as the social order does not stipulate that forcible interference in the spheres of interest 
of the individual may only be resorted to under very definite conditionsnamely, as a reaction against socially harmful interference in the spheres of interest of the individuals, and then only by stipulated individualsso long are there no spheres of interest of the individual protected by the social order. In other words, there is no state of law, which, in the sense developed here, is essentially a state of peace.

\section{THE IDEA OF A COMMUNITY WITHOUT FORCE (NATURAI LAW)}

The result of our investigation thus far is that the specific social technique that we call "law" consists in the establishment of a coercive order by means of which a community monopoly is constituted for applying the measures of coercion decreed by the order. Now the question arises whether this social technique, the law as a social technique, is unavoidable. Perhaps it is only the peculiar content of a social order which makes it necessary to establish this order as a coercive order. Perhaps it is possible to give the social order such a content, to prescribe such conduct for the individuals that it will no longer be necessary to.prescribe coercive measures as sanctions in case of contrary conduct, because the individuals would have no inducement to such contrary behavior. Perhaps there is a social order which would make possible a substitution of direct motivation, of voluntary obedience, for the specific technique of the law. The question of the necessity of the law is identical with the question of the necessity of the State. For the State is a coercive order, is a legal order, a relatively centralized, relatively sovereign, legal order, or, what amounts to the same thing, a community constituted by such a legal order. If the State is defined as a political organization, that is only to say that it is a coercive order. The specifically "political" element consists in nothing but the element of coercion.

History presents no social condition in which large communities have been constituted other than by coercive orders. Even the social community of the most primitive of primitives rests on a religious coercive order, gradually becoming secularized. It is a legal community. The only reason we do not call it a State is because the necessary degree of centralization is still lacking. History confirms the saying: ubi societas, ibi jus. ${ }^{\mathrm{x}}$ Yet man has never been satisfied with this historic fact. He has always desired a condition in which force-even used as sanction-would no longer be exercised by man against man, and therefore there have always been optimists who deem such a condition possible, and political dreamers who believe in a development leading to a "free" society, that is, a society free from all coercion, one in which there will no longer be any law, or, what amounts to the same thing, any State.

I "Wherever there is society, there is law." 
This is the doctrine of theoretical anarchism. This is, fundamentally, the doctrine of so-called natural law, which is distinguishable from positive law by the circumstance that it requires no sanction to be efficacious, and therefore has ceased to be "law," law in the sense that we call the historical orders to be found in social reality, law. He who believes in the existence of a natural law believes in the existence of a social order, the binding character of which results directly from its content. For this order regulates human behavior in a way that corresponds to the nature of men and to the nature of their relationships and is, therefore, a way satisfactory to all the individuals whose conduct is regulated. For this very reason no measures of coercion are required as sanctions for the case of behavior not corresponding to the natural order. For such a possibility is excluded. The natural order is just, that is, it makes all men happy. There is no need to compel people to their own happiness. Hence one needs no State, or, what amounts to the same thing, no positive law. The efficacy of the natural order rests on voluntary obedience. The idea of natural law, in the last analysis, is the anarchistic idea of the Golden Age that Ovid portrays in his classic verses:
Aurea prima sata est aetas, quae vindice nullo, sponte sua, sine lege fidem rectumque colebat. poena metusque aberant, nec verba minantia fixo aere legebantur, nec supplex turba timebat iudicis ora sui, sed erant sine iudice tuti.?

For social pessimism, the Golden Age is the eternally lost paradise of the past. Social optimism places it in the future. It is in either case an illusion, the product of wishful thinking.

If it were really possible for the human mind to fix upon the content of a social order that could reckon on the voluntary obedience of all its subjects, because it corresponded to the nature of man and his mutual relations, because it required of men only what men themselves wished-an order that would make everyone happy and that was therefore a just order, it would be hard to understand why such an order had not yet been realized. For ever since mankind has thought at all, the most illustrious minds have striven to think up such an order, to answer the question of justice. Yet this question is as far from being answered today as it ever was. Of none of the numerous attempts to solve the problem of social technique can it be said that it is anywhere nearly as satisfactory, that is,

2 Ovid, Metam., i, 89-93. "Golden was that first age, which, with no one to compel, without a law, of its own will, kept faith and did the right. There was no fear of punishment, no threatening words were to be read on brazen tablets; no suppliant throng gazed fearfully upon its judge's face; but without judges lived secure." (Translation by Miller, Loeb Classical Library ed. x9x6.) 
that it has come as near general satisfaction, as the solution of any one of the innumerable problems of the technique of natural science. This in itself proves that the much-sought-after natural or just order, if it is discoverable at all, cannot by any means be so constituted that everyone will immediately recognize it as just, and therefore be ready to obey it. On the basis of our knowledge of human nature it must be considered very unlikely that any social order, even one which, in the opinion of its creators, assures to individuals every desired advantage, runs no risk of being violated, and hence need take no precautions to prevent such violations against the will of actual or potential violators, that is, by measures of coercion. It would have to be an order that permitted everyone to do or refrain from doing whatever he wanted. But such an order is in reality the suspension of all social order; it is the reestablishment of a state of nature, which means a state of anarchy.

And this is perhaps the deepest meaning of the idea of a law of nature, of a natural social order: the negation of society, back to nature. This idea proceeds from the notion that man is "by nature" good. It ignores the innate urge to aggression in men. It ignores the fact that the happiness of one man is often incompatible with the happiness of another, and that therefore a natural just order that guarantees happiness to all, and so does not have to react against disturbances with measures of coercion, is not compatible with the "nature" of men as far as our knowledge of it goes. The "nature" of natural law is not the nature of our scientific experience, it is a moral postulate. To count on a human nature different from that known to us is Utopia. This is not to say that human nature is unchangeable, but only that we cannot foresee how it will change under changing circumstances.

The Utopian character of the idea of a social condition not regulated by any coercive order - a society of the future without law or State-appears clearly in the doctrine which has, up to now, most successfully represented this idea politically - the doctrine of Marxian Socialism. ${ }^{3}$ This doctrine explains the necessity of the State and of what it terms "bourgeois" law, by the fact that society is divided into classes-one possessing and the other, without possessions, exploited by the first. According to it the only function of the coercive apparatus represented by the State and its law is to maintain this condition. As soon as the conflict of classes ceases by the abolition of private property and the socialization of the means of production, as well as by planned control of the processes of production, and a classless society has been attained, the apparatus of coercion will become superfluous. In such a social condition, the State "dies"; with it,

3 Compare with the following discussion: Kelsen, Sozialismus und Staat (2d ed. Ig23). 
law disappears. "The government of persons is replaced by the administration of things, and by the conduct of the processes of production."4 The establishment of this condition marks "the rise of mankind from the realm of necessity to the realm of freedom." On the road to this anarchical society, the dictatorship of the proletariat, the proletarian class State, such as exists today in the Union of Socialist Soviet Republics, is only a necessary transition. The political theory of Marxian Socialism is pure anarchism. It is distinguishable from the doctrine directly called "anarchism," as for instance that of Bakunin, not by its aim. The aim is in the one case as in the other, a community constituted without coercion, resting on voluntary obedience of the individiduals, a classless and therefore stateless community. The so-called "anarchists" believe that one can do away with the State at once, whereas Marxists teach that, after the place of the capitalist State has been taken by that of the socialist State, the so-called dictatorship of the proletariat, the State will gradually disappear of itself.

He who thinks that such a stateless society is possible is closing his eyes to the fact that an economic organization such as that which socialism is aiming for, must necessarily have an authoritative character. A planned economy of such immense scope-embracing if possible the whole earthcan only be managed by a gigantic hierarchically organized administrative body, within which each individual, as an organ of the community, will have a definite function to perform, precisely regulated by a normative order. Upon the conscientious observance of these norms depends the productivity of the whole system, and it is just the higher degree of productivity which is to give the planned economy, according to its adherents, the advantage over capitalistic production. If one calls the latter "anarchy" of production, it is because one contrasts it with the socialistic economy which is the opposite of anarchy.5 The norms of the socialistic ordering of the economic life can appear only in the form of commands directed by individuals to individuals, a "government over individuals." Never can "direction of the processes of production" take the place of "government over individuals," as the Marxian theory formulates it. For the processes of production are aggregates of human transactions that proceed according to the scheme of commanding and obeying. A social order that completely regulates the system of economic production and the distribution of the products and is executed by organs of the community must of necessity extend its competence to fields other than economic.

4 Engels, Socialism, Utopian and Scientific 75-77 (translation by Aveling, Kerr ed. I908).

5 There is a notorious contradiction between the economic and the political theory of Marxian Socialism. 
Such a social order, more than any other, has a tendency to become a totalitarian order, which regulates all the cultural realms, and not least, the sexual relations of the individuals. Such an order, more than any other, will need ideological justification, and hence will not leave metaphysical-religious spheres untouched. It must necessarily limit the freedom of the individual much more severely than any State ever has. For this reason alone such a State must count on disturbances on the part of its individuals no less than must the legal orders of bourgeois society.

Let us leave out of consideration here the fact that laziness and stupidity will not quite disappear even in the socialistic community and must here be much more dangerous for the continuance of the order than in a capitalistic State. Let us assume that violations of the legal order of this latter State occur for the most part on economic grounds, and that in the socialistic State such grounds are completely lacking. Still one must assume that here other causes for behavior not corresponding to the order will play so much the greater role. If it is not the incompletely satisfied economic needs of the individual that may lead to a disturbance of the order, it must be other needs-needs arising from his desire for prestige, his libido, and last but not least, from his religious emotions. There may be a difference of opinion about the justification for such needs and the permissible extent of their satisfaction, but their existence cannot be denied. And furthermore one cannot deny that these needs must make themselves felt the more strongly, the more the economic needs are satisfied, and that no solution of the problems arising in this connection is to be expected from the idea of economic socialism. Desire for prestige, libido, and religious emotion are no less revolutionary factors than are hunger and thirst. Only a view that identifies society with economy can fail to see the great dangers that threaten a social order from this direction.

If one must admit that a socialistic order cannot count in all directions upon the voluntary obedience of its subjects, that it, as well as the order of a bourgeois society, must reckon with conduct of individuals not in conformity with the order, then one must also admit that even this order cannot refrain from proceeding against these individuals with measures of coercion, i.e., with measures which, if necessary, must be applied against the will of the individuals acting in a socially harmful manner.

In a socialistic community, prophylactic measures to prevent crimes may be made use of to a greater extent than is possible in the legal community of the capitalistic State. On the basis of our knowledge of such methods in the past, however, we cannot expect that preventive measures can be so effective as to render repressive measures wholly superfluous. 
As long as we remain in the domain of experience, we must assume that even a socialistic order must be a coercive order, and that the State will not die off, but that its order will acquire a different content. Even Socialism cannot get along without the social technique called law. Even in a socialistic society it is true that $u b i$ societas, ibi jus.

\section{THE EVOLUTION OF LEGAL TECHNIQUE}

\section{DIFFERENTIATION OF THE DYNAMIC RELATION BETWEEN} CREATION AND APPLICATION OF LAW

If coercion is an essential element of law in the sense presented here, then every legal order, regarded from a technical point of view, must be presented as a complex of norms in which coercive measures are decreed as sanctions. All other facts to which the legal order applies come into consideration only as conditions of the sanction. The specific technique of the law-the technique of indirect motivation-consists in the very fact that it attaches to certain conditions certain coercive measures as consequences. Morality, whose technique is direct motivation, says, thou shalt not steal. The law says, if one steals, he shall be punished. The moral norm regulates the behavior of one individual; the legal norm, always that of at least two individuals, he whose behavior furnishes the condition of the sanction (the subject) and he whose duty it is to apply the sanction (the organ). The decisive, though not the only, condition of the sanction is that conduct of the subject which, according to the intent of the legal order, should be avoided, the delict. The legal order, by attaching a sanction to this conduct and thus characterizing it as delict, seeks to induce the opposite conduct, that which will not involke the sanction. To say that one has a legal duty to behave in a certain way means that he is threatened with a sanction in case of contrary behavior, that is, in case of a delict. The relation established by the legal norm between delict and sanction is the fundamental relation of the law, insofar as this is regarded in a state of rest. It is the fundamental relation of the statics of the law.

If we now look at the law in its specific movement, that is, if we regard the process of the creation of the law, we observe the fact, of especial significance for the technique of the law, that it regulates its own creation. A norm counts as a legal norm, belongs to a certain legal order only if it has come into being in a certain way, and that, a way stipulated by a norm of the very order. This is the essence of positive law.

There are two methods of creating law: custom, that is, the repeated similar conduct of the subject, and legislation in the broadest sense of the word, that is, the conscious act of a special organ set up for the purpose of creating law. All law is-according to the provisions of the legal order- 
law created by custom or by legislation (in the broadest sense). In this it is distinguishable from natural law, which need not be created by the act of man, since it issues directly from the nature of men or the nature of the relations of men, and as such need only be recognized by man, not created by an act of will.

Positive law not only has to be created, it must be applied. In the progression from creation of the law to its application lie the typical dynamics of the law. It is also characteristic of the technique of the law that these dynamics unfold in at least two stages. The law is first created as a general norm. The application of the general norm to a concrete case consists in the determination whether the condition established by the norm in an abstract manner is present, so that a concrete sanction, determined by the norm only in an abstract fashion, can be decreed or applied in this concrete case. If the application of the concrete sanction is preceded by the decreeing of this sanction, then there are three stages of the dynamic legal process: the creation of the general norm, the creation of the individual norm decreeing the sanction, and the execution of the individual norm. The process of the creation of the general norm may, however, itself be split up into several stages. An' example is the relationship between a constitution and the statutes enacted by the lawmaking body on the basis of that constitution. On the basis of these statutes ordinances or regulations are emitted by the executive organs. These ordinances or regulations are then applied to the concrete case by the judicial or administrative organs. Every legal order forms a hierarchy of general and individual norms, the lowest step of which is the execution of a concrete measure.

The direction of the technical development is that of increasing differentiation among the steps of these legal dynamics. The dynamics of the primitive legal order has only two stages: the development of the general norm through custom, and its application by the subject whose interests, protected by this norm, have been violated. This subject is authorized by the legal order to react against the violator of the law with the sanction provided by the law. Primitive law is characterized by the technique of self-help. Blood revenge is a typical example: the subject himself, whose interests have been violated, and not a special organ, must determine whether or not a delict has been committed. The subject himself must fulfil the sanction without its being decreed by an individual norm, which an organ different from the injured subject must enact and execute. The primitive law of self-help is characterized by the fact that the general norm is applied directly to the concrete instance without being individualized by an individual norm. Only after courts have developed does an 
individual norm insert itself between the general norm and its application to a concrete case, the execution of the sanction. This individual norm is the decree of the sanction by court decision. On the other hand, the process of creation of the general norms also changes in the course of development, so that the dynamic legal process finally is spent in a complicated series of numerous stages.

\section{DIFFERENTIATION OF THE STATIC RELATION BETWEEN DELICT AND SANCTION}

a) Differentiation of the sanction: criminal law and civil law.-Not only the dynamic relation between the creation of law and its application, but also the static relation between delict and sanction is subject to a typical change. Originally there was only one sort of coercive measure-punishment, in the narrower sense of the word; punishment involving life, limb, freedom, or property. The oldest law was only penal law. Later a differentiation in the sanction came about, in that, in addition to punishment, there appeared civil execution, the coercive deprivation of property with the purpose of compensating for illegally caused damage. That is to say that civil law developed along side of penal law. But the civil law, regulating the economic relations of individuals guarantees the behavior desired in this field in a manner not essentially different from that in which penal law does the same thing in its field, namely by establishing in the last analysis, sometimes indirectly, a measure of coercion for the case of contrary conduct-its own specific measure of coercion, civil execution. Penal law is distinguishable from civil law principally through the fact that its sanction has a different character. The difference lies not so much in the outward circumstance of the sanction. The sanction is in both instances a coercive measure, by which the individual in question is divested of possessions. Civil execution involves only property. But this is true also of fines. The difference between penal and civil sanction is rather that the purpose of the latter is to make reparation of the damage caused by the socially harmful conduct, whereas that of the former is retribution, or-according to the modern view-prevention. But this distinction is only relative. For one can hardly deny that the civil sanction also serves as a deterrent, even if only secondarily.

The relative difference between criminal and civil sanction is expressed in the content of the legal order. This legal order contains specific provisions for the use of the property forcibly taken. In the case of civil sanction this property is to be turned over to the illegally wronged subject; in the case of criminal sanction it falls to the legal community.

A further difference is to be found in the procedure that leads to the two sanctions as it has actually developed in the different legal orders. 
The judicial process whose aim is civil execution is initiated only upon demand of a specific subject interested in the execution; the judicial process whose aim is the application of punishment is initiated ex officio, or upon demand of an organ of the community. A civil process has the form of a dispute between two parties, the plaintiff and the defendant; a civil delict is the violation of a right. He who, by his suit, can set in motion the procedure which leads to civil sanction, is the subject of a right.

The according of such rights to the subject and the possibility of pursuing them in a contentious procedure characterize the technique of a legal order that regulates economic life according to the principle of private property. The available economic goods are at the exclusive disposition of private individuals, and this enjoyment of private property is achieved, essentially, by free contract among the individuals. The "right" which the subject has to a thing consists in the power accorded the subject by the legal order to prevent any other subject from interfering with his enjoyment thereof. The specific method of preventing such interference is the possibility accorded by the legal order of setting in motion the coercive process against anyone who disturbs or interferes with the object in that enjoyment.

This power of the subject is a political power, a public function par excellence. But in this system it is ideologically called a specific sphere of "private" interest; the norms granting this power are called "private" law; the power itself, a "private" right. A consequence of this technique of "private" right is that the process by which the general legal norm is applied to the concrete case, the civil sanction decreed and executed against the delinquent, has the character of a contentious procedure. Only in imitation of the civil procedure does the penal procedure in which the criminal sanction is decreed and applied still have the outward character of a dispute, although here no subjective rights usually exist any longer. When, instead of the subject whose interests have been injured by the criminal delict, an organ of the community appears as plaintiff, one can speak only in a very figurative sense of a "right" of the community to cessation of the delict. But even aside from the fact that the application of the legal norm in both civil and criminal law takes place in the form of a contentious procedure, the social technique is in both cases essentially the same: reaction against the delict in the form of an act of coercion as a sanction.

b) Differentiation of the sanction: collective responsibility and individual responsibility.-The delict is a condition of the sanction. It has been demonstrated that one is legally obligated to certain behavior when contrary behavior is threatened with a sanction. The specific sanction of the law 
is an act of coercion-depriving one forcibly of life, health, freedom, or property. Against whom is this sanction directed; whose life, health, freedom, or property is to be forcibly taken away? In accordance with the answer to this question, the technically primitive legal order is distinguished from the technically developed legal order. It corresponds to a more refined sense of justice for the sanction to be directed only against those whose behavior constitutes the legal duty, and whose undutiful behavior, therefore, constitutes the delict as the condition of the sanction. If a legal order forbids murder, that is to say, if it provides a punishment for committing murder, then the punishment is to be directed against the murderer and only the murderer; in other words, against the individual, who, under obligation to abstain from murdering, has, in violation of this duty, committed murder. If we call the individual against whom the sanction is directed the one who is responsible for the delict, then the requirement of the more refined legal technique runs as follows: only he who commits the delict, only the delinquent, is to be responsible for the delict. This is the principle of individual responsibility.

Primitive legal orders, however, do not meet this requirement. It is not contrary to a primitive sense of justice for the sanction to be directed not only against the murderer himself, but against his relatives as well, against all those belonging to his family or his tribe, in other words, against the members of the circumscribed group to which he belongs. Not only he who actually committed the delict is responsible, but others as well. Even in the Bible it is taken as a matter of course that for the sins of the father, the children and the children's children shall be punished. ${ }^{6}$ The circle of those responsible is defined by the fact that they belong to a definite social group, to the same legal community. This is the principle of collective responsibility.

This principle may hark back to the fact that according to primitive conception a very close bond exists between an individual and the other members of his group. Primitive man identifies the individual with his group, with all the other members of it. Primitive man does not regard himself as a self-sufficient individual, different from and independent of his group, but rather as an integral element of it. For him it is a matter of course that each member of the group is responsible for every other member. Just as a heroic deed of one member of the group calls forth satisfaction and pride from all the others, so it is also deemed just that a delict of one member of the group should be avenged on all its members. Collective responsibility is a typical element of the state of justice in which the principle of self-help still subsists. Blood revenge, that typical form of self-

\footnotetext{
'Exodus 20:5.
} 
help, is by no means directed against only the individual who has committed the deed to be avenged, but against his whole family. It is the reaction of one group against another group.

The technical development of the law is characterized by the progress from collective towards individual responsibility.

c) Differentiation of the delict: absolute liability and culpability.-Very closely connected with the difference between individual and collective responsibility is another distinction, which also concerns the solution of the problem of responsibility. To be responsible for a socially harmful or socially useful result, it does not suffice, according to modern, ethical views, for the result actually to have been brought about by one's own conduct. The result must have been brought about in a definite manner. If an individual is to be made responsible for a result brought about by him, he must have intended this result; if it is a question of socially harmful conduct, he must have conducted himself at least negligently.

If the delict consists of certain behavior of the individual involving a socially harmful result, then there must exist between the conduct and its result a specific mental connection that one calls intent or negligence. In order for given behavior to operate as a condition of the sanction, as a delict, it must have this particular mental quality; certain mental elements must be present that one calls "culpa." For example, someone is felling a tree; the falling tree kills a man. If the man felling the tree is made responsible for the death of the person without regard to whether he acted with intent, or with negligence, then it is a case of absolute liability. If, however, the feller of the tree is punished only if he intended by his actions to bring about the death of the man, or if he negligently failed to give warning of the existing danger, then it is a case of culpability. This principle is unknown to primitive legal orders; there the principle of so-called absolute liability prevails. Whoever brings about, no matter how, a result designated by the legal order as socially injurious is punishable. Where the principle of collective responsibility exists, absolute liability is almost unavoidable, for there the sanction is directed to include individuals who have not themselves brought about the result but who merely belong to the same social community as the perpetrator, the individual who did bring about the result by his behavior. If the principle of collective responsibility is supplanted by that of individual responsibility, the way is also made free for the substitution of the principle of culpability for that of absolute liability.

The technical development of the law is characterized by progress not only from collective to individual responsibility, but also from absolute 
liability to culpability. But it should be noted that this is only the formulation of a general rule which exhibits important exceptions. Even in modern legal orders the principle of collective responsibility and that of absolute liability have by no means been given up. Thus the first principle is exhibited in the law of so-called juristic persons; the second, in many spheres of civil law. The form of culpability called "negligence" is not far removed from absolute liability. Especially in international law, both principles are still to be regarded as controlling.

\section{CENTRALIZATION}

Of the greatest importance for the technical development of the law is the process of centralization. Primitive law is in a condition of complete decentralization. It knows as yet no organ functioning according to the principle of the division of labor. All the functions of creation as well as application of the legal norms are performed by all the subjects. Only gradually do special organs develop for the different functions. In the field of law the same process takes place as in that of economic production. Here, too, it is a process of centralization.

In the field of law this process is characterized by the surprising fact that the centralization of the law-applying function precedes the centralization of the law-creating function. Long before special legislative organs come into existence, courts are established to apply the law to concrete cases. The law, thus applied, is customary law, law created by a specific method. The peculiarity of this method is that the general legal norms are created by collaboration of all the individuals subject to the legal order. It is a totally decentralized means of creating law. During thousands upon thousands of years it was the only way of creating general legal norms. The application of the law, however, long ago became the exclusive function of special organs, was long since centralized. No longer is each individual authorized to decide whether or not his rights have been violated, whether or not he will react by a sanction against another individual, responsible for the violation of law. Such decisions have for long been entrusted to a judge, a special organ different from and independent of the parties in conflict. The general norms, however, in accordance with which the judge decides such conflicts, are not always created by a central organ; they still have the character of customary law. Customary law forms an important part of the legal order even in technically highly developed legal communities.

The procedure of applying general legal norms to concrete cases involves-as we have seen-three distinct phases: first, the conditioning 
facts must be established, especially the delict, the concrete violation of law; second, the sanction provided by the general legal norm must be ordered to be applied to the concrete case; and third, this sanction must be executed against the individual responsible for the delict. The three stages of this procedure do not necessarily become centralized at the same time. Historically, the centralization of the first two stages has probably preceded the centralization of the third stage. It was probably first only the establishment of the fact of a concrete violation of the law that was given over to an objective authority, a court.

This step is of the greatest importance. For upon the decision of the question whether or not in a concrete case a delict has been committed depends the possibility of applying to a concrete case the general norm that attaches a sanction to this delict. If a legal order attaches to a certain fact as condition a certain consequence, then it must determine in what manner, and especially by whom, the existence of the conditioning fact is to be established in order that the consequence provided for may be attached to it. It is a fundamental, though often overlooked, principle of legal technique that in the province of law there are no absolute, directly evident facts, no facts "in themselves," but only facts established by the competent authority in a procedure prescribed by the legal order. It is not theft as a fact in itself to which the legal order attaches a certain punishment. Only a layman formulates the rule of law in that way. The jurist knows that the legal order attaches a certain punishment only to a theft established by the competent authority following a prescribed procedure. To say that A has committed a theft can only express a subjective opinion. In the province of law only the authentic opinion, that is, the opinion of the authority instituted by the legal order to establish the fact, is decisive. Any other opinion as to the existence of a fact as determined by the legal order is irrelevant from a juristic point of view.

If the legal order establishes no special organs for determining the conditioning facts, especially the delict, then it is the interested parties themselves that are called upon by the legal order to establish the existence of these facts in the concrete case. Such is the condition of a primitive decentralized legal order. If under such circumstances one subject claims to have been injured by the behavior of another subject and the latter denies it, the essential issue remains undetermined. It can be determined in the sense of a primitive decentralized legal order only by agreement of the parties to the dispute. It is obvious that such agreement can but very seldom be reached. If a subject proceeds without such agreement to an act of coercion against another subject, it is uncertain whether his act 
constitutes a sanction or a delict in the sense of the legal order, that is, whether in this case the legal order was being applied or violated. Hence, for the technical development of the law, no other step was of such importance as the establishment of courts for the determination of the question whether or not in a concrete case a delict was involved. Only by the centralization of this phase of the application of the law was application of the law in all cases possible.

The centralization of the other two phases of the application of the law (the decreeing and the executing of the sanction) is of lesser importance. It seems to be the last step. With it the legal status of self-help by blood revenge is supplanted. In its place appears execution of the sanction by a special organ of the community.

It seems, however, that the state of self-help was only gradually eliminated. In the early days, the courts were hardly more than tribunals of arbitration. They had to decide whether or not the delict had actually been committed, as claimed by one party, and whether or not that party was authorized to execute a sanction against the other, if the conflict could not be settled by peaceful agreement between them. To bring about such a peaceful agreement, enabling the vendetta to be replaced by wergild, was probably the first task of the tribunal. Only at a later stage does it become possible completely to abolish the procedure of self-help, according to which the sanction is executed by the individuals whose interests have been violated by the delict. The execution of the sanction by a central organ of the legal community, authorized to punish the guilty individual, presupposes a concentration of the means of power and the existence of a central organ with all these means of power at its disposal. To centralize the execution of the sanctions provided by the legal order the legal community needs not only courts but also a powerful administration.

A legal community which has an administration and courts is a State. The State, as we have pointed out, is a centralized legal order, or-what amounts to the same-a community constituted by a centralized legal order. From a technical point of view it is very characteristic that a legislative organ is not an essential requisite of a State. It is the centralization of the judicial and administrative, not the lawmaking function, which makes a primitive community a State. The jurisdiction of State courts is older than State legislation.

Although the court preceded the legislative organ, it was not the first central organ. The first central organ was probably the chieftain, in his position as military leader of his group in war against another group. 
Just as the first socially organized sanction, blood revenge, appears in the relation of one group to another, so also centralization was first applied to inter-tribal relations. In the beginning, however, the position of the chieftain was of no importance so far as the formation of intra-tribal law was concerned. As soon as his position becomes a permanent institution and is concerned with intra-tribal legal matters, the chief appears as judge, not as legislator.

Apart from war and the other relations with foreign States, which are regulated by international law, in the beginning of the development the judicial and legislative functions stand in the foreground, the administrative function in the background. In recent times this relationship has changed in favor of the administrative function. The State, from a judicial State, has become an administrative State. This is so, chiefly in the sense that it is no longer only the courts that are called upon to apply the laws but, to an increasing extent, the administrative authorities as well; that side by side with civil and penal laws administrative laws appear in increasing numbers. The latter can achieve the aims of the administration by seeking to bring about by threat of a sanction conduct of the citizen considered desirable by the administration. For example, by a law the citizens are obliged to lay out a public road or to build a school, install instructors, and have their children taught. If they fail to do this, they are punished by special administrative authorities. In such a case the technique of the national administration is the same as that of the national judiciary. This is the type of indirect administration. The type of direct administration of the State is presented by the case where the public road is laid out not by private persons but by public organs, where the school is built not by private persons but by public organs, and instruction furnished not by private persons but by public organs. This activity, termed direct administration, is quite different from the judicial. It appears not among the duties of private subjects, but among the duties of public organs. They are individuals who are characterized in a specific way determined by the legal order. Since the purpose of the administration, even in the case of direct administration, is achieved by individuals being legally obligated to this activity, that is to say that the reaction to contrary conduct is a measure of coercion, even direct administration remains within the framework of the specific technique of the law-indirect motivation.

The development of the State is clearly proceeding in the direction of an accelerated increase in direct administration. The legal technique of direct administration is the technique of the socialistic State in distinction 
to that of the liberal-capitalistic State, which, insofar as it develops administrative activity, prefers the technique of indirect administration. The path from indirect to direct administration of the State is also the path of increasing centralization.

The distinction between centralization and decentralization is, finally, also decisive for the relations among States. International law is a radically decentralized legal order. Its technique reveals all the typical characteristics of a primitive law; the creation by custom of the norms valid for the whole realm of the legal community; no special organs for the application of the general legal norms to the concrete case, but, instead, self-help on the part of the subject whose rights have been injured; collective responsibility, absolute liability. A particular peculiarity of the technique of international law is that its subjects are juristic persons-States. A juristic person is the personification of a legal order, in whole or in part. To say that a legal order obligates and authorizes a juristic person is not to say that it does not obligate and authorize individuals. It means only that the legal order obligates them not directly but indirectly, through the medium of another legal order, the one whose personification is regarded as the subject of the obligating, authorizing legal order. To say that international law obligates and authorizes States means that international law obligates and authorizes individuals in their capacity as organs of the States, individuals who are designated by a national legal order to be organs of this order or of the community constituted by it. That means that the norms of the international legal order are not complete norms; in order to be applied at all they must be supplemented by the norms of the national legal orders. This supplementation consists in the designation of the individuals who, in their capacity as organs of the States, have to fulfil the international duties and to exercise the international rights of the States. This is the rule. As an exception there are also norms of international law determining directly the individuals whose conduct forms the substance of the international duties and rights of the States.

One may assume that the technical development of international law is progressing on the same path as that already taken by the development of the legal orders of the States. Very suggestive is the fact that in international law the centralization has begun with the establishment of courts. Courts are the first relatively centralized organs of international law. To the extent that the direct obligating and authorizing of individuals and centralization increases in international law, the boundary between national and international law tends to disappear, and the legal organization of mankind approaches the idea of a World-State. 